\section{Earnings Management and Quarterly Discretionary Accruals Level in the Brazilian Stock Market}

\author{
Rodolfo Maia Rosado Cascudo Rodrigues ${ }^{1,+}$ (D) \\ ${ }^{1}$ Universidade Federal do Rio Grande do Norte, Natal, RN, Brazil \\ Clayton Levy Lima de Melo ${ }^{2, \Omega}$ (D) \\ ${ }^{2}$ Universidade Federal do Rio Grande do Norte, Natal, RN, Brazil \\ Edilson Paulo ${ }^{3, *}$ (i) \\ ${ }^{3}$ Universidade Federal do Rio Grande do Sul, Porto Alegre, RS, Brazil
}

\begin{abstract}
This study aims to investigate the behavior of the quarterly earnings management level of Brazilian public companies. For this purpose, a sample of 107 companies listed on the B3 Brasil Bolsa Balcáo S.A. was selected and the quarterly discretionary accruals among 2012 and 2017 were estimated using Paulo's (2007) model as a proxy for earnings management. Next, a second regression with the quarterly discretionary accruals and dummy variables representative of each quarter was used. The results indicate that the magnitude average of discretionary accruals are higher in the fourth and last quarter, and discretionary accruals for the first quarter were significantly different from the second and third quarter. These findings suggest that managers adjust the firm's performance report more strongly at the end of the year as it becomes the last opportunity to use discretion over accounting numbers with the intent to achieve annual goals.
\end{abstract}

Keywords: Discretionary accruals; Earnings management; Quarterly statements.

\section{INTRODUCTION}

The accounting system reflects accounting standards that should allow professional judgment so that it can faithfully represent the economic reality of the company, thus giving managers discretion between accounting choices. However, such judgment can be used by management to maximize the wealth of all parties, or as an opportunity to choose methods and estimates that do not reflect the underlying economic performance and favor private gain (HEALY; WAHLEN, 1999; SCHIPPER, 1989; WATTS; ZIMMERMAN, 1990).

In the light of the Signalling Theory, in which the company sends signals to the market in order to try to solve information problems (DALMACIO et al, 2013; LELAND; PYLE, 1977; SPENCE, 1973), the accounting numbers can be understood as signs that aim at reducing informational asymmetry (MORRIS, 1987). These signs are the observable attributes or characteristics of individuals or companies, which they can manipulate by themselves (SPENCE, 1973). 
As a way to increase the transparency and timeliness of the "signs" represented by the reported information, which would minimize agency problems, the main Stock Exchanges met the requirements of market analysts and other users and began to demand that listed companies publish their quarterly financial statements (BROWN; NIEDERHOFFER, 1968). The evidence of Brown and Niederhoffer (1968) pointed out that the periodic statements were useful in forecasting annual profits, and the predictive capacity increased with each new quarterly disclosure.

In the Brazilian market, publicly-held companies are required by the Brazilian Securities and Exchange Commission ( $C V M)$ to disclose quarterly information, in accordance with the $C V M$ Instruction no. 202/93. This frequency becomes more important due to the fact that a greater frequency of disclosure of financial information promotes a reduction in information asymmetry and in the cost of capital (BALL; BROWN, 1968; FU; KRAFT; ZHANG, 2012).

In Brazil, studies on earnings management mainly gained momentum starting in the $2000 \mathrm{~s}$ (AVELAR; SANTOS, 2010; MARTINEZ, 2013). These studies have mostly worked with the companies' annual financial statements, both in the international literature (CALL et al, 2014; DECHOW et al, 2012; DECHOW; SLOAN; SWEENEY, 1995; HEALY; WAHLEN, 1999; KOTHARI; LEONE; WASLEY, 2005), as well as in Brazilian studies (LO, 2008; LUSTOSA et al, 2010; MARTINEZ, 2008; PAULO, 2007; RODRIGUES SOBRINHO; RODRIGUES; SARLO NETO, 2014). Considering that, companies are required to publish quarterly statements, company executives have four annual opportunities to interfere with accounting choices, not just one.

In this quarterly perspective, the fourth quarter is the last opportunity for managers to use discretion to change accounting numbers, since in this quarter managers will have a realistic prognosis of the path that the company's annual earnings are going to (JACOB; JORGENSEN, 2007; KERSTEIN; RAI, 2007). The probability of manipulating the information at the end of the fiscal year in relation to the other periods would also be higher considering the capital market and debt contract incentives (DICHEV; SKINNER, 2002).

Considering this evidence and the need to deepen the discussion about the incentives and levels of earnings management in the quarterly statements which impact investors, analysts, regulators, auditors, tax preparers and users in general, this study aims to investigate the behavior of the quarterly earnings management level of Brazilian publicly traded companies.

In this context, Livnat and Santicchia (2006) drew attention to the fact that it is still unclear whether quarterly accruals have the same pattern as annual accruals. If on the one hand there is evidence that suggests a higher probability of managing earnings in the fourth quarter (COLLINS; HOPWOOD; MCKEOWN, 1984; GUNNY; JACOB; JORGENSEN, 2013; JACOB; JORGENSEN, 2007; KERSTEIN; RAI, 2007), on the other, some studies point out that there is no greater probability, and they do so based on the idea that managers have more freedom to manage (earnings) in the intermediary statements (BROWN; PINELLO, 2007; DEGEORGE; PATEL; ZECKHAUSER, 1999; MENDENHALL; NICHOLS, 1988; SALAMON; STOBER, 1994).

Although some research at the international level has sought to differentiate managing annual earnings from managing quarterly earnings (BROWN; PINELLO, 2007; DAS; SHROFF; ZHANG, 2009; JACOB; JORGENSEN, 2007; KERSTEIN; RAI, 2007; LIVNAT; SANTICCHIA, 2006; YANG; KRISHNAN, 2005), these studies did not seek to estimate and demonstrate the behavior of quarterly discretionary accruals or to measure the magnitude of these accruals over the fiscal period. Therefore, as there is still no consensus on the behavior of quarterly earnings management and the importance of this knowledge for earnings management in literature, an examination of the level of discretionary accruals in the quarters intends to contribute to this discussion. 
This work differs from previous studies and contributes to the national and international literature by measuring the level of discretionary accruals as a proxy for earnings management throughout each quarter of the year, providing evidence of how profits tend to behave, and reflecting the influence of managers on such profits through accruals. In showing the signals issued by companies in the interim statements, the findings also contribute to the discussion on which or in which periods the incentives to manage earnings tend to be stronger.

\section{LITERATURE REVIEW}

Managers have incentives to manage annual earnings, but it can be argued that incentives also apply to quarterly earnings as they add up and form the annual earnings. In this way, managing in the quarterly periods will achieve the earnings level sought for the end of the year (YANG; KRISHNAN, 2005).

Although most accrual studies are emphasizing annual accruals, cash flows and quarterly accruals have relevant information to users in order to warn about a possible reversal in future earnings. In the Brazilian context, there is evidence of managing earnings by accruals as a response to market stimuli in order to avoid reporting losses, maintaining recent performance or decreasing the result (MARTINEZ, 2008) to achieve the analysts' prediction (MARTINS; PAULO; MONTE, 2016), of a negative correlation between taxable profit and earnings management (REZENDE; NAKAO, 2012), of a positive correlation between the levels of distributed dividends and discretionary accruals (RODRIGUES SOBRINHO; RODRIGUES; SARLO NETO, 2014), and that the quality of the accounting information, as measured by discretionary accruals, is not influenced by the issuance of shares and debentures (PAULO; CAVALCANTE; MELO, 2012), nor did it improve after adoption of the International Financial Reporting Standards (IFRS) (GRECCO, 2013). On the other hand, Gioielli, Carvalho and Sampaio (2013) used quarterly data to investigate earnings management in the pre-IPO, IPO, Lock-up and Post-Lock-up phases, and identified that earnings management mainly occurs in the IPO phase.

Accruals are based on estimates and are therefore more susceptible to manipulation than cash flows. In addition, evidence indicates that annual earnings are reached more by accrual adjustments than by operational cash flows (DAS; SHROFF; ZHANG, 2009). The authors also expect that the biggest change in the earnings pattern in the fourth quarter is due to accruals rather than cash flows.

In another line of research, Collins, Hopwood and McKeown (1984) pointed to the occurrence of a higher level of error in analysts' predictions for the fourth quarter for various time periods and for seasonal and non-seasonal firms. In addition, with the exception of the first quarter, forecasting errors increase as the year progresses to its end. Although the authors do not discuss this possibility, in analyzing it from the perspective of earnings management, this finding may be related to the higher volume of discretionary accruals in the last quarter and to the reversal in the first quarter of the following year of accruals managed in the fourth quarter.

The results by Livnat and Santicchia (2006), where companies with extremely high accruals in one quarter tend to have smaller future earnings in the next quarter, also corroborate the logic of accruals reversal. In their research, they also found that these extremely high accruals are also related to negative future returns. These authors warn that analysts should carefully examine quarterly accruals. 
In comparing the earnings coinciding with the fiscal year and the earnings of intermediate quarters in relation to the profit forecast, Doran (1995) showed that the management reports higher profits for the intermediate quarters (first, second and third quarter), finding no bias in the reported earnings at the end of the fiscal year, thereby confirming the idea that not auditing the earnings of the interim periods in the same way as the end-of-year earnings helps managers manage profits in other quarters.

The fourth quarter is when managers are more aware of the company's position on the goals they need to achieve (KERSTEIN; RAI, 2007). Thus, it may happen that managers make estimates for the first three quarters based on good faith, and correct those estimates if necessary in the fourth quarter. However, the absence of an independent audit and a lower volume of disclosure of the information reported in the first, second and third quarters appear as an opportunity for managing the interim earnings (BROWN; PINELLO, 2007).

Jeter and Shivakumar (1999) found that the level of abnormal accruals was higher in the fourth quarter than in the other three quarters of the year, mainly in relation to the second and third quarters, since a high index for discretionary accruals was also found in the first quarter; another finding that may result from the reversal accruals in the first quarter of the previous year. The results show that incentives to achieve predetermined annual earnings prevailed over the idea that the lower degree of audit rigor in the intermediate quarters would increase managerial discretion towards earnings management.

When analyzing intra-day information on disclosure of interim information and fourth quarter information, Lee and Park (2000) point out that market prices adjust faster after the earnings disclosure of the last quarter than after the disclosure of the other periods. They argue that this is explained because investors are more interested in fourth-quarter earnings than in the other three quarters. In addition, they assert that because interim statements are unaudited and often do not present all costs and expenses, it becomes more difficult for the market to assess the value relevance of quarterly profits. These results reinforce the idea that the incentives for earnings management in the last quarter are greater.

Jacob and Jorgensen (2007) used the annual frequency distributions in the first, second and third quarters in comparison to the fourth quarter fiscal year. They presented results consistent with the hypothesis of managing earnings around zero earnings, due to abrupt changes in earnings immediately below zero to positive in the ended quarter, coinciding with the fiscal period. However, this discontinuity around zero was not apparent in the other alternative periods.

Moreover, Kerstein and Rai (2007) considered the group more prone to earnings management being companies that had cumulative earnings close to zero at the end of the fiscal third quarter. The findings indicate that firms which had the lowest accumulated losses at the end of the third quarter started to show the lowest annual profits, thus avoiding disclosure of annual losses.

Das, Shroff and Zhang (2009) studied reversals in the earnings pattern of the other quarters to the fourth quarter of the year, analyzing both the changes from negative to positive, and from positive to negative. The findings of the paper point to significant changes in the discretionary accruals pattern, which combined with other evidence suggest that these reversals in the fourth quarter may come from management. The authors also concluded that the market corrects itself for the changes aimed at increasing profits, while attaching great weight to the changes to reduce earnings. 
Although the results of the aforementioned research indicate the validity of the management hypothesis, the reversals may be due to incidental events, operational decisions and investments, or may be the result of earnings management in the intermediate quarters rather than the latter, which reinforces the need for further studies on the behavior of profits during each quarter of the year (DAS; SHROFF; ZHANG, 2009).

On the other hand, according to the idea that auditing annual statements are more rigid and limit managers' ability to manage earnings, the results by Brown and Pinello (2007) indicate that management to increase earnings is less frequent in the fourth quarter than in the intermediate quarters, and that non-negative (positive) surprises are also less common in the last quarter compared to previous periods.

Considering that the fourth quarter profits are more volatile and have lower response coefficients, Gunny, Jacob and Jorgensen (2013) sought to confront the two explanations for this that have already been reported in the literature: adjustment in the fourth quarter of errors and noise forecasts and estimates for the first three quarters, making profit volatile but of better quality; or earnings management. The results were consistent with the earnings management hypothesis. In addition, the authors concluded that the quality attributes of profit are lower in the twelve months accumulated at the end of the fourth quarter compared to the twelve months accumulated considering the end of the third, second and first quarters.

Although the use of quarterly information has become more frequent in recent studies (CALL et al, 2014; CHOY, 2012; GIOIELLI; CARVALHO; SAMPAIO, 2013; JOIA; NAKAO, 2014; MARTINS; PAULO; MONTE, 2016; MOTA et al, 2017), the present work can contribute to these studies since it conducts an analysis of the quarter factor in the discretionary accruals level of the companies listed on the B3 S/A Brasil Bolsa Balcão (B3) as its main focus, in order to alert researchers that the differentiated characteristics of the quarterly information may cause different analyzes than those carried out with annual information, requiring control for the quarterly factor. In addition, it contributes to better understanding for shareholders, analysts, regulators and other stakeholders of the behavior of figures released quarterly by companies.

\section{METHODOLOGICAL PROCEDURES}

\subsection{DATA AND SAMPLE}

This paper aims to analyze the behavior of earnings management by discretionary accruals in each quarter of the year. For this purpose, the model by Paulo (2007) will be used to calculate discretionary accruals as a proxy for this management. We used quarterly information of Brazilian publicly traded companies with shares traded on the B3 Brasil Bolsa Balcão S.A. (B3) during the period from 2012 to 2017, collected through the Bloomberg database.

In agreement with previous research (LUSTOSA et al., 2010; MARTINEZ, 2008; PAULO, 2007; REZENDE; NAKAO, 2012), financial institutions were excluded from the sample because they had very different accounting standards, in not fully applying the IFRS adopted by other companies in the sample, and consequently having particular and different accruals, as well as due to being firms with high financial leverage, which can lead to estimation problems in the earnings management detection models.

Initially, the analysis was to be initiated in 2010, as this is the year in which Brazilian accounting became fully converged to the International Financial Reporting Standards (IFRS). In addition, the variable Operating Cash Flow (FCO) of the model became readily available to all companies only with the mandatory Cash Flow Statement (CFS) after convergence; therefore, no other measurement or estimation process is required. Kothari (2001) believes 
that cash flow information estimated through the Balance Sheet, an indirect method of FCO estimation, contributes to increase the error in estimating discretionary accruals.

However, as calculating the accruals total as well as some variables of the Paulo model demand lagged information ( $\mathrm{t}-1$ and $\mathrm{t}-2$ ), we decided to start the analysis period in 2012 as a way of increasing the quantity and consistency of the quarterly data used. After the exclusion of financial institutions and companies that did not have all the necessary data, we reached the final sample, as shown in Table 01 below.

Table 01 - Composition of the study sample.

\begin{tabular}{lc}
\hline Total of listed companies on the B3 & 330 \\
\hline (-) Financial Companies & -63 \\
(-) Companies with missing data & -160 \\
(=) Total sample companies & 107 \\
$\left(^{*}\right)$ Amount of quarter under review & 24 \\
$(=)$ Total observations $(\mathrm{N})$ & 2568 \\
\hline
\end{tabular}

Source: Study data (2018).

\subsection{QUARTERLY DISCRETIONARY ACCRUALS ESTIMATION MODEL}

The Paulo model (2007) chosen for the present work is justified for discussing the theoretical problems found in previous models (Sector, Jones, Modified Jones, KS, Pae), and seeking to correct them. Thus, the Paulo model (2007) controls the effects of cash flows, earnings, reversals of accruals, non-linearity of accounting conservatism and the economic sector.

We then have the following econometric configuration for the Paulo model:

$$
\begin{aligned}
& T A_{i t}=\alpha+\beta_{1} R_{i t}+\beta_{3} A \operatorname{Im}_{i t}+\lambda_{1} F C O_{i t}+\lambda_{2} \operatorname{Res}_{i t}+\lambda_{3} \operatorname{Res}_{i t}^{2}+\lambda_{4} \Delta \operatorname{Res}_{i t-1}+ \\
& \lambda_{5} D \Delta \operatorname{Res}_{i t-1}+\lambda_{6} \Delta \operatorname{Res}_{i t-1} * D \Delta \operatorname{Res}_{i t-1}+\lambda_{7} \operatorname{TA}_{i t-1}+\Sigma \beta \text { Setor }+\varepsilon_{i t}
\end{aligned}
$$

In which:

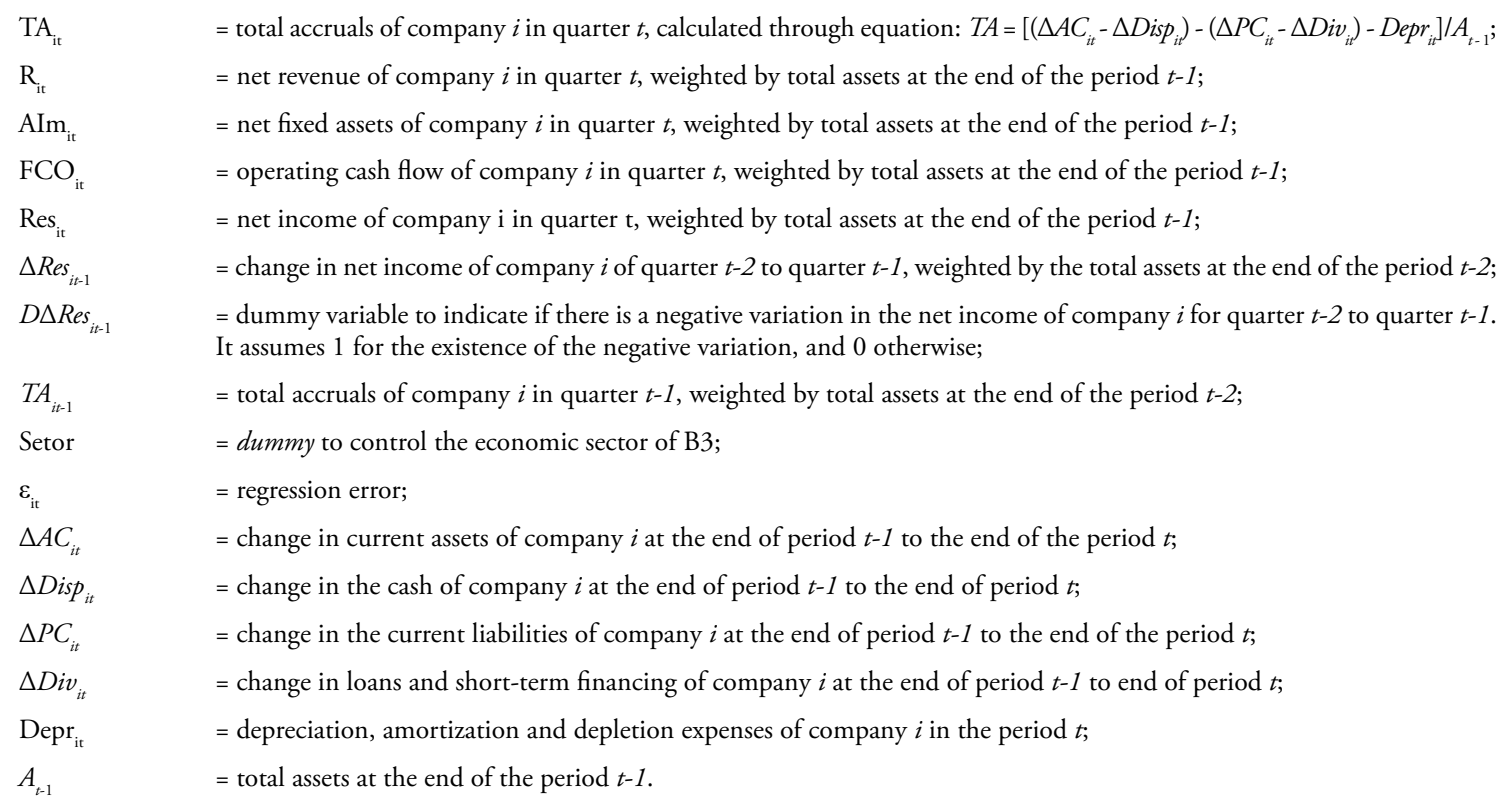


The adopted model does not include the Abnormal Production and Abnormal Operating Expense variables, according to Paulo et al. (2013), as they do not present statistical significance, and therefore do not contribute to increase the explanatory power of the dependent variable.

\subsection{MODEL FOR ANALYSIS OF QUARTERLY DISCRETIONARY ACCRUALS}

In order to achieve the research objectives, it will be necessary to regress the discretionary accruals (DA) in module after their estimation by the Paulo model (2007), in coherence with previous studies (ALMADI; LAZIC, 2016; BERGSTRESSER; PHILIPPON, 2006; CALL et al, 2014; FRANCIS; MAYDEW; SPARKS, 1999a; LI; KUO, 2017; MARTINS; PAULO; MONTE, 2016; REYNOLDS; WARFIELD; WILD; WILD, 1995), by a dummy variable for each quarterly period, with the base equation reflecting the level of discretionary accruals for the first quarter of the year. Thus, the present work intends to only discuss the magnitude of earnings management by accruals, regardless of the management direction.

As discussed by Hribar and Nichols (2007), when using the absolute value of discretionary accruals, it is fundamental to use control variables. Thus, according to previous studies, we used the variables summarized in Chart 01 (below).

Chart 01 - Control variables

\begin{tabular}{|c|c|c|c|c|}
\hline Control & Variable & Notation & Calculation method & Previous studies \\
\hline Size & Total Assets & LnTA & $\begin{array}{l}\text { Natural Logarithm of Total } \\
\text { Assets }\end{array}$ & $\begin{array}{l}\text { Almadi and Lazic (2016); Hribar and Nichols } \\
\text { (2007); Joia and Nakao (2014); Klein (2002); } \\
\text { Marra, Mazzola and Prencipe (2011); Murcia and } \\
\text { Wuerges (2011); Rezende and Nakao (2012); } \\
\text { Rodrigues Sobrinho, Rodrigues and Sarlo Neto } \\
\text { (2014); Xie, Davidson and Dadalt (2003). }\end{array}$ \\
\hline Performance & $\begin{array}{l}\text { Return on } \\
\text { Assets }\end{array}$ & $\mathrm{ROA}$ & $\begin{array}{l}\text { Net Income divided by Total } \\
\text { Assets }\end{array}$ & $\begin{array}{l}\text { Call et al (2014); Joia and Nakao (2014); Rodrigues } \\
\text { Sobrinho, Rodrigues and Sarlo Neto (2014). }\end{array}$ \\
\hline $\begin{array}{l}\text { Operational } \\
\text { Cash Flow }\end{array}$ & $\begin{array}{l}\text { Operational } \\
\text { Cash Flow }\end{array}$ & FCO & Operational Cash Flow & $\begin{array}{c}\text { Barth, Landsman e Lang (2008); Hribar and } \\
\text { Nichols (2007); Joia and Nakao (2014); Marra, } \\
\text { Mazzola and Prencipe (2011); Rodrigues Sobrinho, } \\
\text { Rodrigues and Sarlo Neto (2014); Teoh, Wong and } \\
\text { Rao (1998). }\end{array}$ \\
\hline Growth & Sales growth & Growth & $\begin{array}{l}\text { Percentage change in net } \\
\text { revenue for the quarter in } \\
\text { relation to the same quarter of } \\
\text { the previous year }\end{array}$ & $\begin{array}{l}\text { Barth, Landsman and Lang (2008); Hribar and } \\
\text { Nichols (2007); Rodrigues Sobrinho, Rodrigues and } \\
\text { Sarlo Neto (2014); Teoh, Wong and Rao (1998). }\end{array}$ \\
\hline Leverage & Leverage & Lev & $\begin{array}{l}\text { Total Current Liabilities plus } \\
\text { Long-Term Liabilities divided by } \\
\text { Total Shareholders' Equity }\end{array}$ & $\begin{array}{l}\text { Almadi and Lazic (2016); Call et al. (2014); Barth, } \\
\text { Landsman and Lang (2008); DeFond and Jiambalvo } \\
\text { (1994); Marra, Mazzola and Prencipe (2011). }\end{array}$ \\
\hline
\end{tabular}

Source: Study data (2018).

The following equation is then used to analyze the level of discretionary accruals as proxy for managing quarterly earnings:

$$
\begin{aligned}
& \text { DAabsolute }_{i t}=\alpha_{i t}+\Sigma \beta Q \text { uarter }+\operatorname{LnTA}_{i t}+R O A_{i t}+ \\
& F C O_{i t}+\text { Growth }_{i t}+L_{e v} v_{i t}+\sum \beta S e c t o r+\varepsilon_{i t}
\end{aligned}
$$

In which, Quarter represents dummy for each analyzed quarter and Sector represents the control dummy by sector. 
We chose a second regression to include the control of other idiosyncratic characteristics of the company, as well as to allow for conclusion regarding the first-quarter dummy in the constant, which would not be totally adequate in Paulo's estimation model of discretionary accruals (2007) due to the use of other dummies.

\subsection{DEVELOPMENT OF HYPOTHESES}

Previous literature (DAS; SHROFF; ZHANG, 2009; DICHEV; SKINNER, 2002; LIVNAT; SANTICCHIA, 2006; YANG; KRISHNAN, 2005) has sought to discuss whether incentives for earnings management are more present only in annual or quarterly statements. This discussion raises questions about the behavior and level of quarterly earnings management based on discretionary accruals versus management of annual earnings.

Although Doran (1995) and Brown and Pinello (2007) have evidenced that earnings management in the interim quarters is not different from what was done in the last quarter, even believing that it may be smaller due to the greater rigor employed by Audit in the annual financial statements, the findings by Jeter and Shivakumar (1999), Kerstein and Rai (2007), Jacob and Jorgensen (2007), Das, Shroff and Zhang (2009), and Gunny, Jacob and Jorgensen (2013) suggest that the Fourth quarter earnings management level may be different from the others.

In addition, the high error rate in the analyst's forecast as evidenced by Collins, Hopwood and McKeown (1984), associated with the high magnitude of discretionary accruals for the first quarter, reported by Jeter and Shivakumar (1999), and not being statistically different from the fourth quarter, together with the logic that discretionary accruals of one period tend to be reversed in the following period (CHOY, 2012; DECHOW; DICHEV, 2002; DECHOW et al, 2012; PAULO, 2007), and consequently the first quarter discretionary accrual may account for a large part of the reversal of accrual from the previous period (CHOY, 2012), allowing us to believe that the level of accruals in the first quarter is also statistically different from the second and third quarter.

This means it is possible that earnings management in the first quarter tends to be high due to the accruals reversal of the previous quarter. However, as these accruals may not necessarily be fully reversed in the first quarter (JACOB; JORGENSEN, 2007; CHOY, 2012), they can also be reversed in the second and third quarters. It is believed that the level of the former is higher than that of the second and third, but lower than the fourth.

Thus, the following study hypotheses are made:

H1: Earnings management based on discretionary accruals in the fourth quarter is significantly higher than in the other three quarters.

$\boldsymbol{H}_{2}$ : Earnings management based on discretionary accruals in the first quarter is significantly different from the second and third quarter.

H3: Earnings management based on discretionary accruals in the second and third quarters are not statistically different from each other.

\section{EMPIRICAL RESULTS AND DISCUSSION}

\subsection{EsTIMATION OF DISCRETIONARY ACCRUALS}

The estimation of discretionary accruals as a proxy for managing quarterly earnings occurred through the regression residual of the Paulo model (2007). The descriptive statistics for all model variables, including the estimated discretionary accruals (DAit), as well as the specification tests performed, can be seen in Table 02, below. 
BBR

16,3

The means of the total accruals variables ( and ) were negative, with variability measured by standard deviations of 0.07241 and 0.07348 . This means that companies are generally showing higher cash flows than earnings, which may also indicate that there is a reduction in the working capital of these companies (DECHOW; DICHEV, 2002).

Considering the objective of analyzing the same companies for all the analyzed quarters in order to enable monitoring of the management behavior of quarterly earnings, and the influence of the particular characteristics of each company of the sample throughout the whole period, we decided to organize the data through a balanced panel using fixed effects approach, according to the significance of the Hausman test, and with standard errors robust to heterocedasticity.

Thus, the coefficients for the regression of the Paulo model after the performed tests are shown in Table 03. The statistics of the sectors are omitted due to the fixed effects approach.

Table 02 - Descriptive statistics and specification tests - Paulo model (2007)

\begin{tabular}{|c|c|c|c|c|c|}
\hline Variable & $\mathrm{N}$ & Mean & Standard Deviation & Minimum & Maximum \\
\hline$T a_{i t}$ & 2568 & -0.00819 & 0.07241 & -1.48752 & 1.01662 \\
\hline$R_{i t}$ & 2568 & 0.19572 & 0.14546 & -0.00105 & 1.03456 \\
\hline$A \operatorname{Im}_{i t}$ & 2568 & 0.26896 & 0.20630 & 0.00041 & 0.94380 \\
\hline$F C O_{i t}$ & 2568 & 0.01709 & 0.04291 & -0.73954 & 0.51395 \\
\hline Resit & 2568 & 0.00596 & 0.04918 & -0.53073 & 1.07385 \\
\hline $\operatorname{Res} 2_{i t}$ & 2568 & 12.30738 & 96.27033 & 0.00000 & 2976.10 \\
\hline$\Delta \operatorname{Res}_{i t-1}$ & 2568 & 0.00061 & 0.06250 & -1.14253 & 1.09304 \\
\hline$D \Delta \operatorname{Res}_{i t-1}$ & 2568 & 0.50896 & 0.50002 & 0.00000 & 1.00000 \\
\hline$\Delta \operatorname{Res}_{i t-1}{ }^{*} D \Delta \operatorname{Res}_{i t-1}$ & 2568 & -0.00972 & 0.04042 & -1.14253 & 0.00000 \\
\hline$T A_{i t-1}$ & 2568 & -0.00818 & 0.07348 & -1.48752 & 1.01662 \\
\hline$A D_{i t}$ absoluto & 2568 & 0.03326 & 0.05745 & 0.00000 & 1.44679 \\
\hline Description & Value & & Description & Value & \\
\hline VIF & 1.40 & & Hausman test & 0.0000 & \\
\hline \multirow[t]{2}{*}{ Shapiro-Wilk's test } & 0.0000 & & Chow test & 0.0000 & \\
\hline & & & Wald test & 0.0000 & \\
\hline
\end{tabular}

Source: Study data (2018).

Table 03 - Estimate of earnings management - Paulo model (2007)

\begin{tabular}{|c|c|c|c|c|}
\hline$T A_{i t}$ & Coef. & Std. Error & $\mathrm{t}$ & $P>|t|$ \\
\hline$R_{i t}$ & 0.0988 & 0.0643 & 1.54 & 0.128 \\
\hline $\operatorname{AIm}_{i t}$ & -0.0245 & 0.0240 & -1.02 & 0.310 \\
\hline$F C O_{i t}$ & -0.5142 & 0.1521 & -3.38 & $0.001^{* * *}$ \\
\hline $\operatorname{Res}_{i t}$ & 0.4733 & 0.1437 & 3.29 & $0.001^{* * *}$ \\
\hline $\operatorname{Res} 2_{i t}$ & -0.0000 & 0.0000 & -0.93 & 0.356 \\
\hline$\Delta \operatorname{Res}_{i t-1}$ & 0.0874 & 0.0347 & 2.52 & $0.013^{* *}$ \\
\hline$D \Delta \operatorname{Res}_{i t-1}$ & 0.0043 & 0.0027 & 1.61 & 0.111 \\
\hline$\Delta \operatorname{Res}_{i t-1}{ }^{*} D \Delta \operatorname{Res}_{i t-1}$ & 0.0538 & 0.0512 & 1.05 & 0.296 \\
\hline$T A_{i t-1}$ & -0.1663 & 0.0586 & -2.84 & $0.005^{* * *}$ \\
\hline Constante & -0.0177 & 0.0112 & -1.58 & 0.117 \\
\hline Descrição & Value & & Description & Value \\
\hline $\mathrm{N}$ & 2568 & & $R^{2}$ within & 0.2069 \\
\hline Grupos & 107 & & $R^{2}$ between & 0.0224 \\
\hline $\mathrm{N}$ por grupo & 24 & & $R^{2}$ overall & 0.1683 \\
\hline F-statistic & 29.86 & & & \\
\hline Prob $>$ F & 0.0000 & & & \\
\hline
\end{tabular}

Source: Research data (2018).

Notes: ${ }^{* *}$ Significant at $5 \% .{ }^{* * *}$ Significant at $1 \%$. 
The $\mathrm{TA}_{i t}$ variable presented a positive relationship with earnings and negative with the FCO, consistent with that found by Dechow and Dichev (2002). In addition, it presented a significance level of $1 \%$, convergent to the findings by Paulo (2007), a fact that corresponds to previous studies that used the Paulo (2007) model (MOTA et al., 2017; PAULO, 2007); the Total Accrual variable of the previous period, which represents the accrual reversal, also presented significance at $1 \%$, and a negative relationship with the dependent variable.

\subsection{ANALYSIS OF THE MANAGEMENT LEVEL OF QUARTERLY EARNINGS}

\subsubsection{DESCRIPTIVE STATISTICS OF QUARTERLY DISCRETIONARY ACCRUALS}

Before analyzing the significance of quarterly discretionary accruals, it is important to analyze the separate descriptive statistics of such accruals considering all quarters included in the review period (1T2012 to 4T2017 - Table 04), as well as consolidated by quarters (1T, 2T, 3T, 4T - Table 05).

Table 04 - Discretionary accruals statistics for all quarters.

\begin{tabular}{|c|c|c|c|c|c|c|}
\hline$D A_{i t}$ absolute & $\mathrm{N}$ & Mean & Median & Minimum & Maximum & $\begin{array}{l}\text { Standard } \\
\text { Deviation }\end{array}$ \\
\hline 1T2012 & 107 & 0.03933 & 0.01988 & 0.00121 & 0.49382 & 0.06139 \\
\hline $2 \mathrm{~T} 2012$ & 107 & 0.03113 & 0.02016 & 0.00090 & 0.27347 & 0.04050 \\
\hline 3Т2012 & 107 & 0.02440 & 0.01555 & 0.00008 & 0.12813 & 0.02566 \\
\hline 4T2012 & 107 & 0.04590 & 0.02408 & 0.00010 & 0.49780 & 0.06373 \\
\hline $1 \mathrm{~T} 2013$ & 107 & 0.03603 & 0.01663 & 0.00046 & 0.48215 & 0.06143 \\
\hline $2 \mathrm{~T} 2013$ & 107 & 0.03001 & 0.01997 & 0.00032 & 0.38768 & 0.04343 \\
\hline 3 T2013 & 107 & 0.03082 & 0.01706 & 0.00034 & 0.22766 & 0.04153 \\
\hline 4T2013 & 107 & 0.03720 & 0.02729 & 0.00037 & 0.32255 & 0.04300 \\
\hline 1T2014 & 107 & 0.02621 & 0.01306 & 0.00003 & 0.26630 & 0.04115 \\
\hline 2T2014 & 107 & 0.02983 & 0.01924 & 0.00015 & 0.35919 & 0.04571 \\
\hline 3Т2014 & 107 & 0.03853 & 0.01893 & 0.00022 & 0.71851 & 0.08556 \\
\hline 4T2014 & 107 & 0.03636 & 0.02506 & 0.00018 & 0.18758 & 0.03432 \\
\hline 1T2015 & 107 & 0.02711 & 0.02307 & 0.00034 & 0.14784 & 0.02475 \\
\hline $2 \mathrm{~T} 2015$ & 107 & 0.02177 & 0.01549 & 0.00031 & 0.13583 & 0.02331 \\
\hline 3 T2015 & 107 & 0.04331 & 0.02786 & 0.00008 & 0.45844 & 0.06090 \\
\hline 4T2015 & 107 & 0.04729 & 0.02164 & 0.00031 & 0.60850 & 0.08099 \\
\hline 1T2016 & 107 & 0.02763 & 0.01706 & 0.00017 & 0.26415 & 0.03566 \\
\hline 2T2016 & 107 & 0.02399 & 0.01529 & 0.00020 & 0.22457 & 0.03098 \\
\hline 3Т2016 & 107 & 0.02511 & 0.01420 & 0.00043 & 0.31844 & 0.03926 \\
\hline 4T2016 & 107 & 0.05091 & 0.02240 & 0.00006 & 1.44679 & 0.15477 \\
\hline 1T2017 & 107 & 0.02798 & 0.01512 & 0.00000 & 0.42020 & 0.04977 \\
\hline 2Т2017 & 107 & 0.03045 & 0.01778 & 0.00032 & 0.19651 & 0.03793 \\
\hline 3Т2017 & 107 & 0.03233 & 0.01938 & 0.00021 & 0.27597 & 0.04312 \\
\hline 4T2017 & 107 & 0.03460 & 0.02251 & 0.00008 & 0.26378 & 0.04376 \\
\hline \multicolumn{7}{|c|}{ Source: Research data (2018). } \\
\hline \multirow{2}{*}{$D A_{i t}$ absolute } & d disc & . & & & & \\
\hline & $\mathrm{N}$ & Mean & Median & Minimum & Maximum & $\begin{array}{l}\text { Standard } \\
\text { deviation }\end{array}$ \\
\hline $1 \mathrm{~T}$ & 642 & 0.03072 & 0.01704 & 0.00000 & 0.49382 & 0.04769 \\
\hline $2 \mathrm{~T}$ & 642 & 0.02786 & 0.01757 & 0.00015 & 0.38768 & 0.03779 \\
\hline $3 \mathrm{~T}$ & 642 & 0.03242 & 0.01825 & 0.00008 & 0.71851 & 0.05316 \\
\hline $4 \mathrm{~T}$ & 642 & 0.04204 & 0.02382 & 0.00006 & 1.44679 & 0.08108 \\
\hline
\end{tabular}


The averages for all quarters indicate that the highest averages of the absolute discretionary accrual values are in the fourth quarter of 2016 and in the fourth quarter of 2015 , with 0.05091 and 0.04729 , respectively, which may suggest a higher level of earnings management in fourth quarters. In addition, Table 6 shows that the fourth quarter averages represent the highest absolute $\mathrm{DA}_{i t}$ for the years 2012, 2013 and 2017. In other words, in 2014 alone, the highest absolute $\mathrm{DA}_{i t}$ level is not presented in the fourth quarter, being slightly higher in the third quarter (0.03853). It is therefore 0.04590 for the fourth quarter of 2012, 0.03720 for the fourth quarter of 2013 and 0.03460 for the fourth quarter of 2017; results confirmed by the average presented in Table 05 (0.04204) of all fourth quarters, and in line with Hypothesis 1.

In analyzing the consolidated averages of each quarter of Table 05, it can be seen (as discussed in previous paragraphs) that the fourth (0.04204) and third (0.03242) quarters present the highest averages, followed by the first $(0.03072)$ and second quarter $(0.02786)$. It was also observed that the fourth quarter also shows the greater dispersion around the discretionary accrual, measured by the standard deviation of 0.08108 .

In order to obtain a better understanding of the behavior of quarterly discretionary accruals, the calculated means of Tables 04 and 05 were placed in two line graphs, leading to Graphs 01 and 02 , which can be visualized below:

In the first two years under investigation (2012 and 2013), accruals presented a significant value for the first quarter, followed by two consecutive reductions in the second and third quarters, and then a prominent high in the fourth quarter, reaching its peak. The second highest value in the first quarter of these years, just behind the fourth quarter, may be indicating the reversal of the discretionary accrual for the fourth quarter of the previous period.

In 2014, the magnitude of the discretionary accrual has the lowest level in the first quarter, increasing from the first to the third period and with a large variation from the second to the third, when it then shows a slight decrease in the level from the third to the fourth quarter.

Graph 01 - Discretionary accrual averages for all quarters

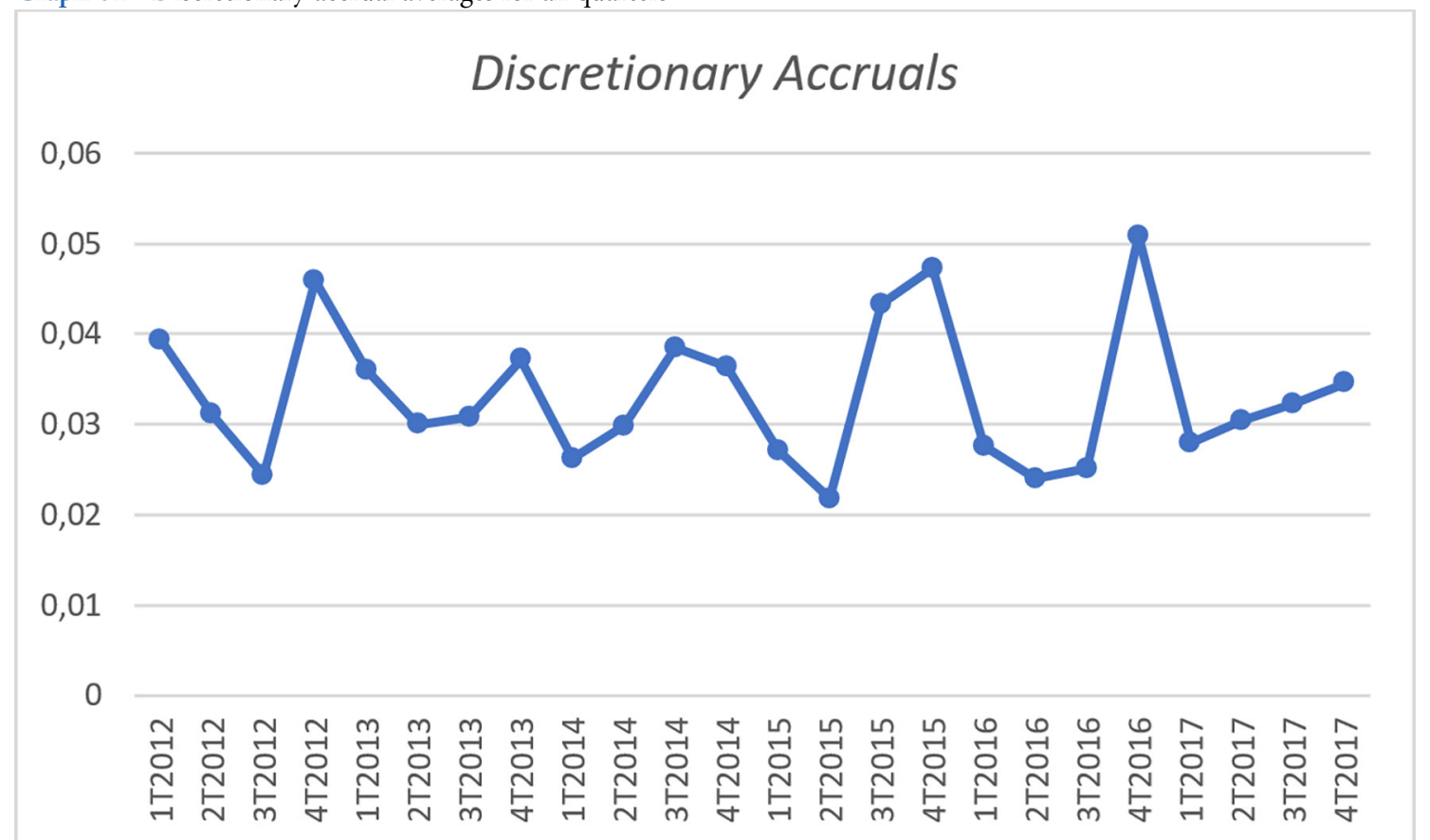

Source: Research data (2018). 


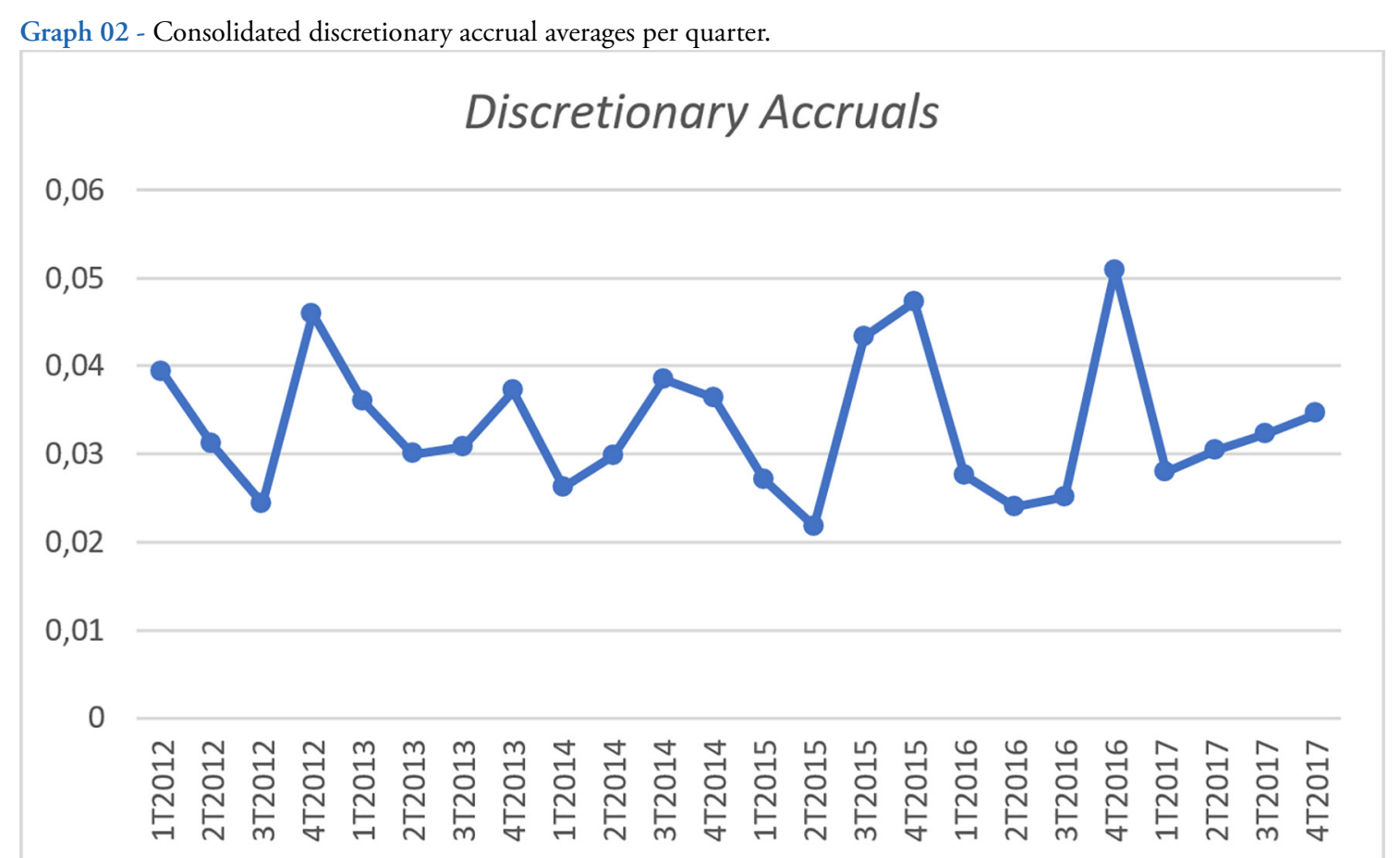

Source: Research data (2018).

By 2015, the lowest value occurs in the second quarter, followed by the first, third and fourth quarter. As is clear from Graph 01 in 2015, there is a reduced magnitude in the discretionary accrual from the first to the second quarter, after which there is a sharp increase from the second to the third quarter, until reaching the maximum in the fourth quarter.

The behavior observed in 2016 differs from 2015, as the first quarter of 2016 presents a higher discretionary accrual value than the third quarter, marked by a sharp increase for the fourth quarter. Finally, the magnitude of the discretionary accrual in 2017 is increasing from the first to the fourth quarter, meaning that the lowest value is for the first quarter, followed by the second and third, reaching the maximum value in the fourth quarter.

This behavior of discretionary accruals in the years 2014 and 2015, in which the third quarter stands out for a high level of earnings management, unlike the one observed for the years of 2012 and 2013, may be related to the serious Brazilian economic crisis in that period, marked by the strong general reduction in economic activity and followed by periods of recession, causing a decrease in revenues and earnings of most Brazilian companies.

Although in 2016, still marked by the economic recession, this strong earnings management in the third quarter is not observed, while the fourth quarter of that year has the highest discretionary accrual value of the whole studied series. In observing the year 2017 in Graph 02, a year in which economic growth resumed, there was a general decrease in discretionary accrual averages in relation to previous years, and smaller variations between quarters, corroborating the idea of greater management in the years of crisis.

When analyzing Graph 02 with the consolidated averages per quarter, the last quarter is the highest earnings management period in relation to the others. The third is in second place on this management scale, but with average numbers very close to the level found in the first quarter. Finally, we have the second quarter as the lowest amount for discretionary accruals. 
Thus, in an attempt to understand this behavior, and relating it to the intentions of managers in manipulating earnings, it can be suggested that due to the reversal accruals from the last quarter of the previous year (JACOB; JORGENSEN, 2007; CHOY, 2012), the first quarter presents a higher level of discretionary accruals than the second quarter, when managers do not yet act strongly in accounting numbers of companies, and therefore have the smallest magnitude. Thus, from the third quarter onwards an increase in the number of actions in the accounting choices would be achieved in order to reach the goals pre-determined by management to reach its apex in the fourth quarter, which would be the last chance to reach these goals (GUNNY; JACOB; JORGENSEN, 2013; KERSTEIN; RAI, 2007).

\subsubsection{REGRESSION ANALYSIS OF QUARTERLY EARNINGS MANAGEMENT}

The descriptive statistics for the regression variables of the quarterly discretionary accruals with the quarterly dummies and the control variables by the fixed effects approach, with standard errors robust to heteroscedasticity, as well as the performed specification tests, can be seen in Table 06. The regression results are shown in Table 7.

Table 06 - Descriptive statistics and specification tests - quarterly regression.

\begin{tabular}{lccccc}
\hline Variable & $\mathrm{N}$ & Mean & Standard Deviation & Minimum & Maximum \\
\hline$D A_{i t}$ absolute & 2568 & 0.03326 & 0.05745 & 0.00000 & 1.44679 \\
LnTA & 2568 & 8.48214 & 1.82963 & 2.75175 & 13.7446 \\
ROA & 2568 & 0.00531 & 0.04816 & -0.56617 & 0.75588 \\
FCO & 2568 & 0.01709 & 0.04291 & -0.73954 & 0.51395 \\
Growth & 2568 & 0.07992 & 0.81412 & -25.61237 & 16.78596 \\
Lev & 2568 & 1.73143 & 11.79420 & -322.51850 & 353.36640 \\
\hline Descriçáo & Value & & Description & Value & \\
VIF & 1.38 & Hausman Test & 0.0150 & 0.0000 \\
Shapiro-Wilk Test & 0.0000 & Chow Test & 0.0000 & \\
& & Wald Test &
\end{tabular}

Source: Research data (2018).

Table 07 - Regression analysis of quarterly earnings management.

\begin{tabular}{lcccc}
\hline DA $A_{\text {it }}$ absolute & Coef. & Std. Error & $\mathrm{T}$ & $\mathrm{P}>|\mathrm{t}|$ \\
\hline Constant & 0.2244 & 0.0892 & 2.52 & $0.013^{* *}$ \\
$D T 2$ & -0.0024 & 0.0030 & -0.80 & 0.423 \\
$D T 3$ & 0.0028 & 0.0037 & 0.76 & 0.447 \\
DT4 & 0.0120 & 0.0045 & 2.70 & $0.008^{* * *}$ \\
LnTA & -0.0230 & 0.0105 & -2.19 & $0.031^{* *}$ \\
ROA & 0.1579 & 0.1026 & 1.54 & 0.127 \\
FCO & 0.0183 & 0.1243 & 0.15 & 0.883 \\
Growth & -0.0000 & 0.0022 & -0.02 & 0.981 \\
\hline Lev & 0.0000 & 0.0000 & 0.77 & 0.444 \\
\hline Description & Value & & Description & Value \\
N & 2568 & & $R^{2}$ within & 0.0400 \\
Group & 107 & & $R^{2}$ between & 0.1104 \\
N per group & 24 & $R^{2}$ overall & 0.0331 \\
F-statistic & 5.67 & & & \\
Prob $>$ F & 0.0000 & & & \\
\hline
\end{tabular}

Source: Research data (2018).

Notes: ${ }^{*}$ Significant at $10 \% .{ }^{* *}$ Significant at $5 \% .{ }^{* *}$ Significant at $1 \%$. 
The positive signs presented for the DT3 and DT4 coefficients show that the magnitude of the discretionary accruals in these periods tend to be larger than in the others. On the other hand, the DT2 has a negative sign, indicating that the value of the discretionary accrual tends to be smaller in the second quarter. These results confirm the initial evidence discussed in the previous section regarding the average of quarterly discretionary accruals.

In analyzing the significance of the variables of interest in order to investigate whether the level of earnings management happens differently between quarters throughout the year, we can see that the fourth quarter was significant at $1 \%$ with a p-value of 0.008 , as well as the constant in which the coefficient of the first quarter is contained was significant at $5 \%$, thereby suggesting that these quarters have different levels of earnings management.

The probable explanation for the significance of the first quarter is the reversal of the discretionary accrual of the fourth quarter in the previous year into the first quarter of the following year, as expected by the study. Regarding the DT2 and DT3 variables, we observed that there was no significance with $p$-value values of 0.423 and 0.447 , respectively.

Differently from what DeGeorge, Patel and Zeckhauser (1999) and Dichev and Skinner (2002) found, the results of this research are in line with the evidence of Lee and Park (2000) and Kerstein and Rai (2007), according to which the incentives for earnings management in the last quarter of the year are higher, and therefore are also higher for the annual statements.

The level of significance for the discretionary accruals of the fourth quarter corroborates the results by Jeter and Shivakumar (1999), Jacob and Jorgensen (2007), Kerstein and Rai (2007), Das, Shroff and Zhang (2009) and Gunny, Jacob and Jorgensen (2013), while the level of discretionary accruals for the first quarter agrees with the findings by Jeter and Shivakumar (1999), as well as being consistent with the major prediction errors of the analysts in the fourth and first quarters reported by Collins, Hopwood and McKeown (1984). This implies that such periods present statistically different levels of earnings management compared to the second and third quarters, contrary to what is suggested by Doran (1995) and Brown and Pinello (2007).

Based on descriptive analyzes and regression significance coefficients for the analysis of managing quarterly earnings, it is possible to make conclusions regarding the hypotheses of the research, according to Chart 02.

Chart 02 - Analysis of hypotheses

\begin{tabular}{|c|l|c|}
\hline Hypotheses & Description & Result \\
\hline $\mathrm{H}_{1}$ & $\begin{array}{l}\text { Earnings management based on discretionary accruals in the fourth quarter is significantly } \\
\text { bigher than in the other three quarters. }\end{array}$ & Not rejected \\
\hline $\mathrm{H}_{2}$ & $\begin{array}{l}\text { Earnings management based on discretionary accruals in the first quarter is significantly } \\
\text { different from the second and third quarter. }\end{array}$ & Not rejected \\
\hline $\mathrm{H}_{3}$ & $\begin{array}{l}\text { Earnings management based on discretionary accruals in the second and third quarters } \\
\text { are not statistically different from each other. }\end{array}$ & Notected \\
\hline
\end{tabular}

Source: Research data (2018). 


\subsection{SENSITIVITY ANALYSIS}

As a way to verify the robustness of the results, we performed two sensitivity tests on the initially employed model to analyze the management of quarterly earnings and the level of discretionary accruals. The first one considered the discretionary accrual regression as a dependent variable, as well as the quarterly dummy variables and the control variables, but with the $\mathrm{DA}_{i t}$ variable in its original form, which means considering the positive or negative signs, and not in the module. The second test involved the direct inclusion of quarterly dummies in the implemented Paulo (2007) model. By these analyzes only the variable of the fourth quarter continued to be significant at $5 \%$ and $10 \%$, respectively.

In both analyzes, the second and third quarters remained unimportant. The sensitivity analyzes suggest that the conclusions regarding the non-rejection of Hypotheses 1 and 3 remained valid, but it reinforces the need to continue investigating the behavior of quarterly discretionary accruals, especially those estimated for the first quarter.

\section{FINAL CONSIDERATIONS}

This research sought to contribute to earnings management literature by studying the management level behavior of quarterly earnings in the Brazilian stock market. For this, it estimated discretionary accruals for the quarters between 2012 and 2017 of 107 nonfinancial companies listed in the B3, using the Paulo model (2007). Next, we sought to analyze the behavior of the average of discretionary accruals over the entire analysis period, as well as consolidated by quarter.

The results indicate that the highest discretionary accruals average in the module occurs in the fourth quarter. In addition, in analyzing the year-to-year averages we also observed that the fourth quarter is the most intense period of earnings management, except for 2014. Through the year-to-year analysis, we are also able to verify that the first quarter was the second period of the largest magnitude of discretionary accruals in the years of 2012, 2013 and 2016. In 2014, 2015 and 2017, this behavior changes and the third quarter assumes this position; a fact that may be related to the economic crisis present in Brazil during this period.

Regression analysis with quarterly discretionary accruals as a dependent variable and quarterly dummies as independent variables presented statistical significance at $1 \%$ for the fourth quarter and 5\% for the first quarter, while the second and third quarters were not significant. These results allowed us to not reject the assumptions that earnings management based on discretionary accruals in the fourth quarter is significantly higher than in the other three quarters (Hypothesis 1), which deals with earnings management based on first quarter discretionary accruals being significantly different (Hypothesis 2), and that earnings management based on discretionary accruals of the second and third quarters are not statistically different (Hypothesis 3).

However, it was only possible to confirm the results for the $\mathrm{H} 1$ and $\mathrm{H} 3$ hypotheses by the sensitivity analyzes, thus indicating the need for further studies on the first quarter discretionary accrual behavior.

Therefore, the results of this research suggest that managers' discretionary behavior affects the accounting numbers reported quarterly by companies and may influence the perception of their investors, shareholders and other stakeholders. For scientific research, it is evidenced that earnings management by accruals presents different variations throughout the quarters, which should be considered in future studies. 


\section{REFERENCES}

ALMADI, M.; LAZIC, P. CEO incentive compensation and earnings management: The

implications of institutions and governance systems. Management Decision, v. 54, n. 10, p. 2447-2461, 2016.

AVELAR, E. A.; SANTOS, T. S. Gerenciamento de resultados contábeis: uma análise das pesquisas realizadas no Brasil entre os anos de 2000 e 2009. Revista de Contabilidade do Mestrado em Ciências Contábeis da UERJ (online), v. 15, n. 3, p. 19-33, 2010.

BALL, R.; BROWN, P. An empirical evaluation of accounting income numbers. Journal of Accounting Research, v. 6, n.2, p-159-178, 1968.

BARTH, M. E.; LANDSMAN, W. R.; LANG, M. H. International Accounting Standards and Accounting Quality. Journal of Accounting Research, v. 46, n. 3, p. 467-498, 2008.

BERGSTRESSER, D.; PHILIPPON, T. CEO incentives and earnings management. Journal of Financial Economics, v. 80, p. 511-529, 2006.

BROWN, P.; NIEDERHOFFER, V. The predictive content of quarterly earnings. The Journal of Business, v. 41, n. 4, p. 488-497, 1968.

BROWN, L. D.; PINELLO, A. S. To what extent does the financial reporting process curb earnings surprise games? Journal of Accounting Research, v. 45, n. 5, p. 947-981, 2007.

CALL, A. C. et al. Short-term earnings guidance and accrual-based earnings management. Review of accounting studies, v. 19, p. 955-987, 2014.

CHOY, H. L. Assessing earnings management flexibility. Review of Accounting and Finance, v. 11, n. 4, p. 340-376, 2012.

COLLINS, W. A.; HOPWOOD, W. S.; MCKEOWN, J. C. The Predictability of Interim Earnings over Alternative Quarters. Journal of Accounting Research, v. 22, n. 2, p. 467-479, 1984.

COMISSÃO DE VALORES MOBILIÁRIOS (CVM). Instrução CVM nº 202, de 06 de dezembro de 1993. Brasília, DF, 1993.

DALMACIO, F. Z et al. Uma análise da relação entre governança corporativa e acurácia das previsões dos analistas do mercado brasileiro. Rev. Adm. Mackenzie, v. 14, n. 5, p.104-139, 2013.

DAS, S.; SHROFF, P. K.; ZHANG, H. Quarterly earnings patterns and earnings management. Contemporary Accounting Research, v. 26, n. 3, p. 797-831, 2009.

DECHOW, P. M; DICHEV, I. D. The quality of accruals and earnings: the role of accrual estimation errors. The Accounting Review, v.77, p.35-59, 2002.

DECHOW, P. M.; SLOAN, R. G.; SWEENEY, A. P. Detecting earnings management. The Accounting Review, v. 70, n. 2, p. 193-225, 1995.

DECHOW, P.; et al. Detecting earnings management: a new approach. Journal of Accounting Research, v. 50, n. 2, p. 275-334, 2012.

DEFOND, M. L.; JIAMBALVO, J. Debt covenant violation and manipulation of accruals. Journal of Accounting and Economics, v. 17, p. 145-176, 1994.

DEGEORGE, F.; PATEL, J.; ZECKHAUSER, R. Earnings management to exceed thresholds. The Journal of Business, v. 72, n. 1, p. 1-33, 1999.

DICHEV, I. D.; SKINNER, D. J. Large-sample evidence on the debt covenant hypothesis. Journal of Accounting Research, v. 40, n. 4, p. 1091-1123, 2002.

DORAN, D. T. Earnings performance and interim reporting. Journal of Applied Business Research, v. 11, n. 1, p. 67-72, 1995.

FRANCIS, J. R.; MAYDEW, E. L.; SPARKS, H. C. The role of Big 6 auditors in the credible reporting of accruals. Auditing: A Journal of Practice \& Theory, v. 18, n. 2, p. 17-34, 1999a.

FU, R.; KRAFT, A.; ZHANG, H. Financial reporting frequency information asymmetry and the cost of equity. Journal of Accounting and Economics, v. 54, p. 132-149, 2012.

GIOIELLI, S. P. O.; CARVALHO, A. G. de; SAMPAIO, J. O. Venture capital and earnings management in IPOs. Brazilian Business Review, v. 10, n. 4, p. 30-64, 2013.

GRECCO, M. C. P. The Effect of Brazilian convergence to IFRS on earnings management by listed Brazilian nonfinancial companies. Brazilian Business Review, v. 10, n. 4, p. 110-132, 2013.

GUNNY, K. A.; JACOB, J.; JORGENSEN, B. N. Implications of the integral approach and earnings management for alternate annual reporting periods. Review of Accounting Studies, v. 18, n. 3, p. 868-891, 2013.

HEALY, P. M.; WAHLEN, J. M. A review of the earnings management literature and its implications for standard setting. Accounting Horizons, v. 13, n. 4, p. 365-383, 1999. 
HRIBAR, P.; NICHOLS, D. C. The Use of Unsigned Earnings Quality Measures in Tests of Earnings Management. Journal of Accounting Research, v. 45, n. 5, p. 1017-1053, 2007.

JACOB, J.; JORGENSEN, B. N. Earnings management and accounting income aggregation. Journal of Accounting and Economics, v. 43, n. 2, p. 369-390, 2007.

JETER, D. C.; SHIVAKUMAR, L. Cross-sectional estimation of abnormal accruals using quarterly and annual data: effectiveness in detecting event-specific earnings management. Accounting \& Business Research, v. 29, p. 299-319, 1999.

JOIA, R. M.; NAKAO, S. H. Adoção de IFRS e gerenciamento de resultado nas empresas de capital aberto. Revista de Educação e Pesquisa em Contabilidade, v. 8, n. 1, p. 22-38, 2014.

KERSTEIN, J.; RAI, A. Intra-year shifts in the earnings distribution and their implications for earnings management. Journal of Accounting and Economics, v. 44, n. 3, p. 399-419, 2007.

KLEIN, A. Audit committee, board of director characteristics, and earnings management. Journal of Accounting and Economics, v. 33, p. 375-400, 2002.

KOTHARI, S. P. Capital markets research in accounting. Journal of Accounting and Economics, v. 31, n. 1, p. 105-231, 2001.

KOTHARI, S. P.; LEONE; Andrew J.; WASLEY, Charles E. Performance matched discretionary accrual measures. Journal of Accounting and Economics, v. 39, p. 163-197, 2005.

LEE, J.; PARK, C. W. Intraday stock price reactions to interim-quarter versus fourth-quarter earnings announcements. Journal of Business Finance \& Accounting, v. 27, n. 7, p. 1027-1046, 2000.

LELAND, H. E.; PYLE, D. H. Informational asymmetries, financial structure, and financial intermediation. The Journal of Finance, v. 32, n. 2, p. 371-387, 1977.

LI, L.; KUO, C. CEO equity compensation and earnings management: The role of growth opportunities. Finance Research Letters, v. 20, p. 289-295, 2017.

LIVNAT, J.; SANTICCHIA, M. Cash flows, accruals, and future returns. Financial Analysts Journal, v. 62, n. 4, p. 48-61, 2006.

LUSTOSA, P. R. B; et al. Estimativas contábeis e qualidade do lucro: análise setorial no Brasil. Revista de Educação e Pesquisa em Contabilidade (REPeC), v. 4, n. 2, p. 43-61, 2010.

MARRA, A.; MAZZOLA, P.; PRENCIPE, A. Board monitoring and earnings management pre- and postIFRS. The International Journal of Accounting, v. 46, p. 205-230, 2011.

MARTINEZ, A. L. Detectando earnings management no Brasil: estimando os accruals discricionários. Revista Contabilidade \& Finanças, v.19, n.46, p.7-17, 2008.

MARTINEZ, A. L. Earnings management in Brazil: a survey of the literature. Brazilian Business Review, V. 10, n. 4, p. 1-29, 2013.

MARTINS, V. G.; PAULO, E.; MONTE, P. A. do. O gerenciamento de resultados contábeis exerce influência na acurácia da previsão de analistas no Brasil? Revista Universo Contábil, v. 12, n. 3, p. 73-90, 2016.

MENDENHALL, R.; NICHOLS, W. D. Bad news and differential market reactions to announcements of earlier-quarters versus forth-quarters earnings. Journal of Accounting Research, v. 26, p. 63-86, 1988.

MORRIS, R. D. Signalling, agency theory and accounting policy choice. Accounting and Business Research, v. 18, n. 69, p. 47-69, 1987.

MOTA, R. H. G. et al. Previsão de lucro e gerenciamento de resultados: evidências empíricas no mercado acionário brasileiro. Revista Universo Contábil, v. 13, n. 1, p. 06-26, 2017.

MURCIA, F. D.; WUERGES, A. Escolhas contábeis no mercado brasileiro: divulgação voluntária de informações versus gerenciamento de resultados. Revista Universo Contábil, v. 7, n. 2, p. 28-44, 2011.

PAULO, E.; CAVALCANTE, P. R. N.; MELO, I. I. S. L. de. Qualidade das informações contábeis na oferta pública de ações e debêntures pelas companhias abertas brasileiras. Brazilian Business Review, v. 9, n. 1, p. 1-26, 2012.

PAULO, E. Manipulação das informações contábeis: uma análise teórica e empírica sobre os modelos operacionais de detecção de gerenciamento de resultados. 2007. 2 v. Tese (Doutorado em Ciências Contábeis) - Universidade de São Paulo, São Paulo, 2007.

PAULO, E.; et al. The Impact of the Adoption of International Financial Reporting Standards on the Quality of Accounting Information of the Brazilian and European Public Firms. SSRN, 2013. Disponível em: $<$ http://papers.ssrn.com/sol3/papers.cfm?abstract_id=2270678 $>$. Acesso em: 19.mar.2017.

REZENDE, G. P.; NAKAO, S. H. Gerenciamento de resultados e a relação com o lucro tributável das empresas brasileiras de capital aberto. Revista Universo Contábil, v. 8, n. 1, p. 06-21, 2012.

RODRIGUES SOBRINHO, W. B.; RODRIGUES, H. S.; SARLO NETO, A. Dividendos e accruals discricionários: um estudo sobre a relação entre a política de distribuição de dividendos e a qualidade dos lucros. Revista Contemporânea de Contabilidade, v.11, n.24, p.03-24, 2014. 
SALAMON, G. L.; STOBER, T. L. Cross-quarter differences in stock price responses to earnings announcements: fourth-quarter and seasonality influences. Contemporary Accounting Research, v. 11, n. 1, p. 297-330, 1994.

SCHIPPER, K. Commentary on earnings management. Accounting Horizons, v. 3, n. 4, p. 91-102, 1989.

SPENCE, A. M. Job market signaling. The Quarterly Journal of Economics, v. 83, n. 3, p. 355-374, 1973.

TEOH, S. H.; WONG, T. J.; RAO, G. R. Are Accruals during Initial Public Offerings Oportunistic? Review of Accounting Studies, v. 3, p. 175-208, 1998.

WARFIELD, T. D.; WILD. J. J.; WILD, K. L. Managerial ownership, accounting choices, and informativesess of earnings. Journal of Accounting and Economics, v. 20, p. 61-91, 1995.

WATTS, R.; ZIMMERMAN, J. L. Positive Accounting Theory: a ten year perspective. The Accounting Review, v. 65, n. 1, p. 131-156, 1990.

XIE, B.; DAVIDSON, W. N.; DADALT, P. J. Earnings management and corporate governance: the role of the board and the audit committee. Journal of Corporate Finance, v. 9, p. 295-316, 2003.

YANG, J. S.; KRISHNAN, J. Audit committees and quarterly earnings management. International Journal of Auditing, v. 9, p. 201-219, 2005. 